\title{
Rancang Bangun Alat Kontrol dan Monitoring Konsumsi Listrik Lampu Penerangan Jalan Umum Berbasis Mikrokontroler ATMega 2560
}

\author{
I Putu Surya Puja Anggara ${ }^{1}$, A.A Ngurah Amrita ${ }^{2}$, Duman Care Khrisne ${ }^{3}$
}

\begin{abstract}
The design of the tool in this study made a prototype of the Public Street Lighting System (LPJU) where in carrying out it can carry out LPJU ignition control according to user needs by combining the timer and light sensor functions. The light setting will strengthen slowly at 18.00 WITA. The light will start to light with the light sensor bit value $<500$, then when the sunlight decreases around the light sensor which is bright compared to the average value produced up to $<200$ then the maximum lamp light. Then at $>00.00$ WITA to $<04.00$ WITA, the power light was reduced by 11.6 lux. At 04.00 WITA it can increase the strong lights and can set the lights off at 06.00 WITA. In addition, it can also monitor electricity consumption regularly and at any time use SMS services to users.

Intisari-Rancang bangun alat pada penelitian ini membuat sebuah prototype sistem Lampu Penerangan Jalan Umum (LPJU) dimana dalam implementainya dapat melakukan kontrol penyalaan LPJU sesuai dengan kebutuhan user dengan mengkombinasi fungsi timer dan sensor cahaya. Pengaturan nyala lampu akan menguat secara perlahan yang diatur pada pukul 18.00 WITA. Lampu akan mulai menyala dengan dimmer pada nilai bit sensor cahaya $<500$, kemudian saat semakin berkurangnya intensitas cahaya matahari di sekitar sensor cahaya yang berbanding lurus dengan perubahan nilai bit yang dihasilkan sampai dengan <200 maka lampu menyala maksimal. Kemudian pada >pukul 00.00 WITA sampai <pukul 04.00 WITA dapat menurunkan kuat pencahayaan lampu sebesar 11,6 lux. Pada > pukul 04.00 WITA dapat meningkatkan kembali kuat pencahayaan lampu dan dapat mengatur waktu padam lampu pada pukul 06.00 WITA. Selain itu juga dapat melakukan monitoring konsumsi listrik secara berkala dan sewaktu-waktu menggunakan layanan SMS kepada user.
\end{abstract}

Kata Kunci-Kontrol, Monitoring, Mikrokontroler, SMS.

\section{Pendahuluan}

Berdasarkan data pengelolaan LPJU di Kota Denpasar, kendala yang dihadapi dalam pengelolaan LPJU adalah masalah pemeliharaan, monitoring, dan konsumsi konsumsi daya listrik yang besar. Beberapa upaya pengelola sudah dilakukan untuk menanggulangi kendala tersebut dalam hal kontrol penyalaan lampu untuk meminimalkan konsumsi daya

\footnotetext{
${ }^{1}$ Mahasiswa, Program Studi Teknik Elektro Fakultas Teknik Universitas Udayana, Perumahan Nuansa Kori Sading I No.I, Mengwi, Badung 80351 INDONESIA (tlp:089 702390 39; e-mail: surya_pooja182@yahoo.co.id)

2, 3 Dosen, Program Studi Teknik Elektro Fakultas Teknik Universitas Udayana, Jln. Jalan Kampus Bukit Jimbaran 80361 INDONESIA (telp: 0361-703315; fax: 0361-4321; e-mail: ngramrita@unud.ac.id, duman@unud.ac.id)
}

listrik LPJU dengan memasang timer atau sensor cahaya I Putu Surya Puja Anggara: Rancang Bangun Alat Kontrol ... untuk mengatur penyalaan lampu. Selain itu juga pemasangan $\mathrm{kWh}$ meter konvensional pada satu sistem LPJU untuk monitoring konsumsi daya listriknya. Akan tetapi dalam upaya tersebut, kondisi di lapangan masih menghadapi beberapa kendala yaitu dalam kontrol penyalaan lampu yang tidak sesuai dengan kebutuan pencahayaan dan keterbatasan tenaga melakukan monitoring konsumsi listrik karena cakupan wilayah yang luas dengan titik pemasangan LPJU yang sangat banyak sehingga akan banyak menghabiskan waktu pekerjaan dan biaya yang tinggi [1].

Manfaat penelitian ini diharapkan dapat melakukan kontrol waktu penyalaan dan kuat pencahayaan lampu sesuai dengan kebutuhan dan juga mengatasi masalah keterbatasan tenaga dalam melakukan monitoring konsumsi daya listrik.

\section{TINJAUAN MUTAKHIR}

Beberapa penilitian sebelumnya yang memiliki keterkaitan dengan penelitian ini, antara lain adalah:

1. Penelitian oleh William Timotius S. pada tahun 2014 dengan merancang bangun alat sebagai dimmer dan monitoring pada sistem LPJU. Menggunakan mikrokontroler ATMega 128 sebagai pengolah data dan sensor gerak sebagai indikator dimmer lampu. Pemodelan sistemnya adalah saat sensor gerak mendektesi pergerakan dari pengguna jalan maka lampu akan menyala maksimal, tetapi apabila sensor gerak tidak mendeteksi adanya pergerakan maka kuat pencahayaan lampu akan redup $60 \%$ dari kuat pencahayaan maksimal. Selain itu juga rancang bangun alat ini memiliki kemampuan monitoring kerusakan pada satu sistem LPJU dengan mendeteksi ketidak normalan arus pada sumber lampu, jika terjadi gangguan alat akan mengirimkan informasi berupa layanan SMS ke user sebagai pemberitahuan gangguan pada sistem LPJU [2].

2. Penelitian oleh T. Syamsuri pada tahun 2015 dengan merancang bangun alat pada sistem LPJU yang dapat melakukan dimmer. Perancangannya menggunakan 2 (dua) kondisi lampu dimana lampu 1 menyala sepanjang malam dan lampu 2 melakukan dimmer. Menggunakan monostable multivibrator IC555 sebagai pengolah data dan sensor cahaya sebagai indikator penyalaan lampu. Pemodelan sistemnya saat sensor cahaya mendeteksi cahaya lampu kendaraan yang melintas maka lampu 1 dan lampu 2 lampu akan menyala, sebaliknya jika tidak maka lampu 2 akan padam dan lampu 1 tetap menyala [3].

Dibandingkan dengan penelitian sebelumnya, beberapa perbedaan pada penelitian ini adalah :

1. Mengkombinasi fungsi timer dan sensor cahaya sebagai indikator penyalaan lampu.

p-ISSN:1693 - 2951; e-ISSN: 2503-2372 
2. Dapat menghitung dan mengakumulasi konsumsi daya listrik pada sistem LPJU yang dirancang dengan perkalian arus AC dan tegangan AC yang diukur pada rangkaian.

3. Merekam data (data logger). Data logger merupakan sistem yang menggunakan perangkat elektronik seperti micro SD card sebagai sarana penyimpanan data [4]. Data yang disimpan berupa akumulasi konsumsi daya listrik.

4. Menggunakan mikrokontroler Arduino ATMega 2560 sebagai pengolah data menggunakan program [5]. Kelebihan Arduino ATMega 2560 adalah memiliki lebih banyak pin input dan output sebanyak 54 buah pin [6].

5. Menggunakan modul GSM IComSat v1.1-SIM900 GSM/GPRS Shield for Arduino sebagai penyedia layanan SMS sehingga dapat melakukan monitoring dengan jangkuan operasi yang lebih luas [6].

6. Memiliki display LCD untuk menampilkan informasi data waktu, tegangan, arus dan konsumsi daya listrik sehingga mempermudah pembacaan oleh user.

\section{METODELOGI}

A. Pemodelan Sistem

Rancang bangun alat penelitian ini memiliki 2 (dua) konsep sistem kerja yaitu melakukan kontrol penyalaan lampu dan monitoring konsumsi listrik.

\section{Kontrol Penyalaan Lampu}

Dalam operasi kerjanya kontrol penyalaan lampu menggunakan indikator yang mengkombinasi fungsi rangkaian timer dan sensor cahaya. Timer memberi akses informasi waktu berupa penunjukan jam penyalaan dan jam pemadaman lampu menggunakan rangkaian RTC DS1307. Berdasarkan penunjukan jam penyalaan lampu, lampu hanya akan menyala berdasarkan nilai sensor cahaya. Sensor cahaya akan menghasilkan nilai bit berdasarkan intensitas cahaya yang diterimanya menggunakan rangkaian LDR.

Lampu menyala dilakukan dengan mengatur nilai PWM pada pengolahan program mirokontroler. PWM merupakan pengaturan lebar pulsa High dan Low (Duty Cycle) dengan nilai 0 sampai 255 dalam suatu perioda untuk mendapatkan tegangan keluaran rata-rata yang berbeda [6]. Kontrol penyalaan lampu maksimal menggunakan nilai PWM $=100 \%$, lampu dimmer dengan nilai $\mathrm{PWM}=50 \%$, dan lampu padam dengan nilai $\mathrm{PWM}=0 \%$.

\section{Monitoring Konsumsi Listrik}

Monitoring konsumsi listrik yang dilakukan adalah melakukan data logger akumulasi konsumsi daya listrik selama rangkaian beroperasi yang disimpan pada micro $S D$ card. Kemudian mengirimkan informasi data logger menggunakan layanan SMS secara berkala dari LPJU ke user. Selain itu monitoring konsumsi listrik juga dapat dilakukan sewaktu-waktu oleh user ke LPJU dengan mengirim SMS sesuai format yaitu "lapor".

Dalam operasi kerjanya akumulasi konsumsi daya listrik dilakukan dengan pembacaan nilai tegangan (V) dan arus (A) pada jaringan listrik PLN yang mensuplai rancang bangun alat saat beroperasi. Hasil pembacaan ini kemudian di olah dan dikalibrasi pada program mikrokontroler untuk mendapatkan nilai akumulasi kWh. Akumulasi konsumsi daya listrik pada pengolahan program mikrokontroler menggunakan perkalian $\mathrm{V}$ dan A dengan cos $\phi$ diabaikan [7].

Pemodelan sistem kontrol penyalaan lampu dan monitoring konsumsi listrik pada penelitian ini dengan merancang sebuah prototype LPJU dengan keterangan gambar yang ditunjukan pada Gambar 1 berikut.

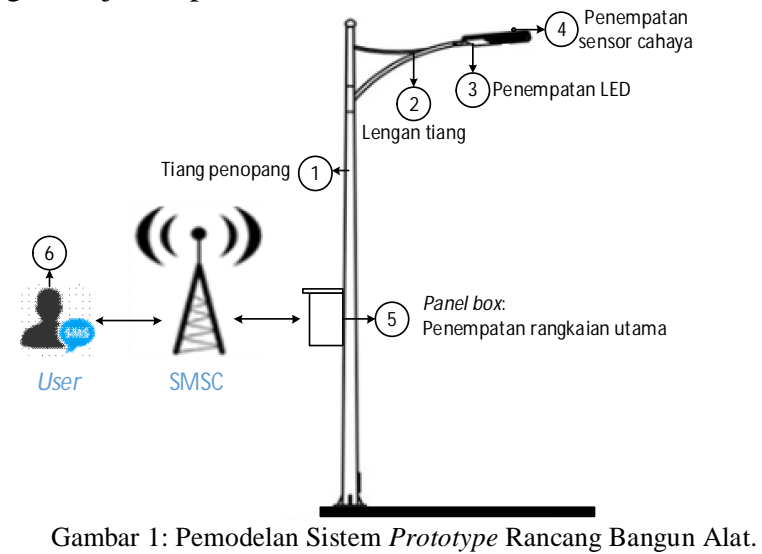

B. Perancangan yang dilakukan:

1. Perancangan Perangkat Keras

Dilakukan dengan merancangan perangkat keras komponen elektronik yang terbagi dalam beberapa blok rangkaian. Rangkaian pada penelitian ini berupa :

a. Rangkaian LCD (Liquid Crystal Display).

b. Rangkaian sensor arus AC.

c. Rangkaian sensor tegangan AC.

d. Rangkaian sensor cahaya.

e. Rangkaian RTC (Real Time Clock).

f. Rangkaian micro $S D$ card.

g. Rangkaian modul GSM IComSat v1.1 - SIM900.

h. Rangkaian LED.

Berdasarkan perancangan setiap blok rangkaian tersebut perakitan setiap blok perangkat keras selanjutnya disebut dengan rangkaian utama. Rangkaian utama dapat digambarkan dengan sebuah blok diagram perancangan perangkat keras yang ditunjukan pada Gambar 2.

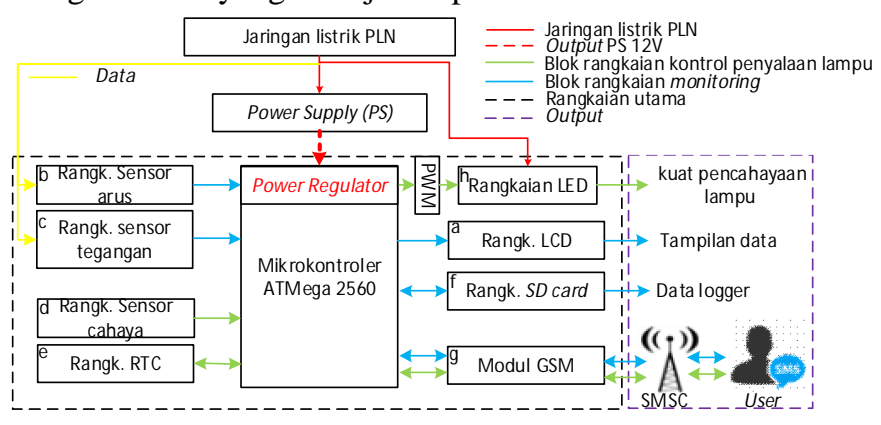

Gambar 2: Blok Diagram Perancangan Perangkat Keras

\section{Perancangan Perangkat Lunak}

Perancangan perangkat lunak merupakan rancangan program pada mikrokontroler terhadap setiap blok rangkaian komponen perangkat keras yang digunakan pada rangkaian utama. Perancangan ini dilakukan dengan mengatur program mikrokontroler sesuai dengan library yang digunakan pada Arduino IDE [8] dengan alur yang ditunjukan pada Gambar 3 sebagai berikut. 


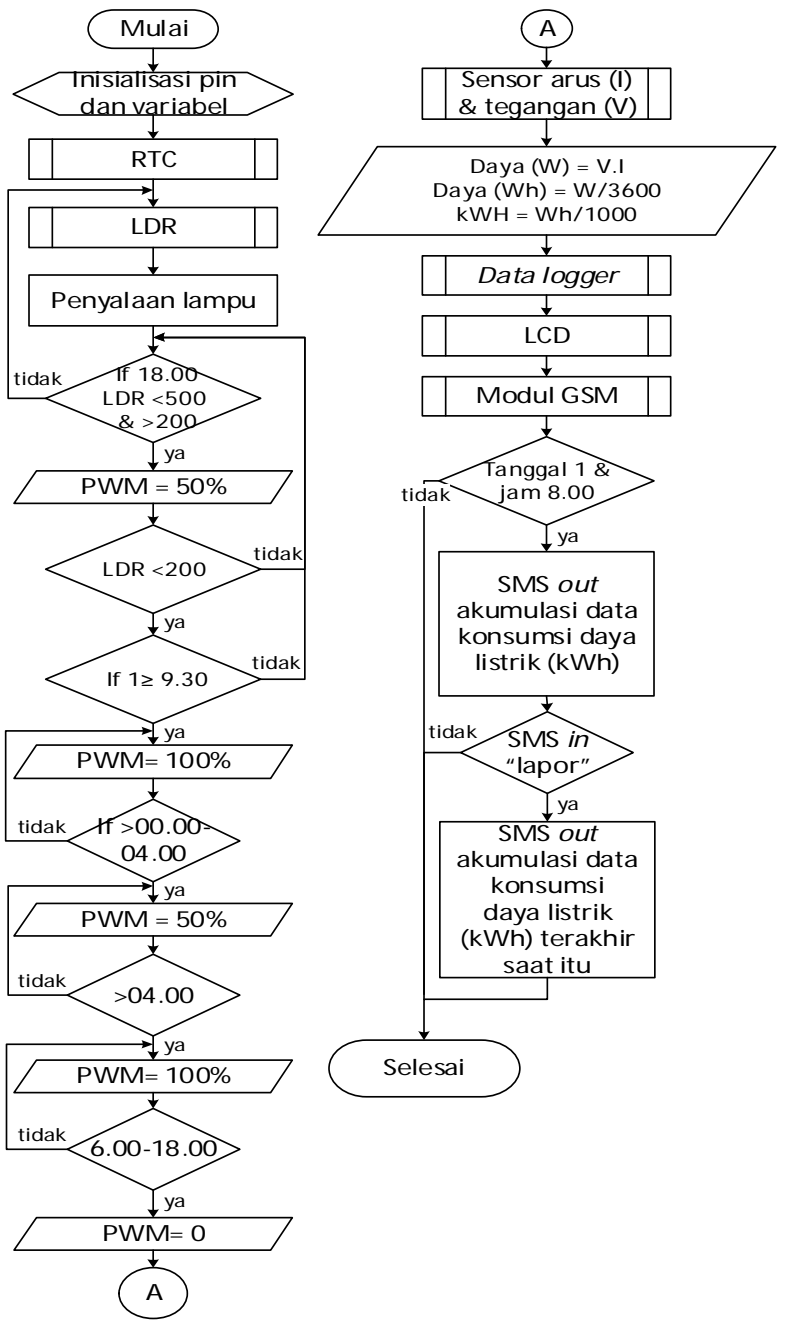

Gambar 3: Blok Diagram Alur Perangkat Lunak

\section{HASIL DAN PEMBAHASAN}

A. Hasil Realisasi Perancangan.

Hasil perakitan rangkaian utama dan prototype LPJU ditunjukan pada Tabel I sebagai berikut.

TABEL I

SPESIFIKASI RANGKAIAN UTAMA DAN PROTOTYPE LPJU

\begin{tabular}{|c|c|c|}
\hline No. & Spesifikasi & Keterangan \\
\hline 1 & Ukuran PCB rangkaian utama & $12 \times 11 \mathrm{~cm}$ \\
\hline 2 & Tinggi tiang & $200 \mathrm{~cm}$ \\
\hline 3 & Panjang lengan lampu & $40 \mathrm{~cm}$ \\
\hline 4 & Ukuran panel box & $16 \times 10 \times 23 \mathrm{~cm}$ \\
\hline 5 & Display LCD & $20 \times 4$ karakter \\
\hline
\end{tabular}

B. Pengujian Rangkaian Perangkat Keras.

Pengujian dilakukan untuk mengetahui realisasi perancangan rangkaian pada setiap blok perangkat keras dapat beroperasi dengan baik. Berikut pengujian yang dilakukan:

1. Pengujian Rangkaian LCD

Pada pengujiannya rangkaian LCD dapat beroperasi dengan baik dan karakter alphanumeric pada LCD berhasil di tampilkan sesuai perintah program yang di berikan.

2. Pengujian Rangkaian Sensor Arus AC
Pengujian ini dilakukan untuk memenuhi syarat alat ukur dengan toleransi kesalahan nilai sebesar 1-2\% [9]. Perangkat keras yang dirancang sebelumnya telah dikalibrasi sesuai dengan library perangkat lunak yang digunakan [8].

Pengujian dilakukan dengan membandingkan nilai arus hasil pembacaan rangkaian sensor arus AC dengan multi tester konvensional kelas B (Hioki 3288-20) dengan mengukur arus pada jaringan listrik PLN sebanyak 10 kali. Percobaan I dilakukan dengan mengukur jaringan listrik yang mensuplai rangkaian utama sedangkan percobaan II dilakukan dengan mengukur jaringan listrik yang mensuplai rangkaian utama dengan penambahan beban lampu LED. Berdasarkan pengujian yang dilakukan, selisih nilai pembacaan paling besar adalah 0,02 Ampere (A) yang ditunjukan pada Tabel II berikut.

TABEL II

Hasil Pengujian RangKaian Sensor Arus AC

\begin{tabular}{|c|c|c|c|c|}
\hline \multirow[b]{2}{*}{ No. } & \multirow[b]{2}{*}{ Percobaan } & \multicolumn{2}{|c|}{ Hasil Pembacaan } & \multirow[b]{2}{*}{ Selisih } \\
\hline & & Multi tester & $\begin{array}{c}\text { Sensor } \\
\text { Arus AC }\end{array}$ & \\
\hline 1 & \multirow{5}{*}{ I } & $0,06 \mathrm{~A}$ & $0,07 \mathrm{~A}$ & $0,01 \mathrm{~A}$ \\
\hline 2 & & $0,07 \mathrm{~A}$ & $0,08 \mathrm{~A}$ & $0,01 \mathrm{~A}$ \\
\hline 3 & & $0,07 \mathrm{~A}$ & $0,08 \mathrm{~A}$ & $0,01 \mathrm{~A}$ \\
\hline 4 & & $0,06 \mathrm{~A}$ & $0,07 \mathrm{~A}$ & $0,01 \mathrm{~A}$ \\
\hline 5 & & $0,07 \mathrm{~A}$ & $0,08 \mathrm{~A}$ & $0,01 \mathrm{~A}$ \\
\hline 6 & \multirow{5}{*}{ II } & $0,17 \mathrm{~A}$ & $0,15 \mathrm{~A}$ & $0,02 \mathrm{~A}$ \\
\hline 7 & & $0,16 \mathrm{~A}$ & $0,15 \mathrm{~A}$ & $0,01 \mathrm{~A}$ \\
\hline 8 & & $0,15 \mathrm{~A}$ & $0,15 \mathrm{~A}$ & $0 \mathrm{~A}$ \\
\hline 9 & & $0,15 \mathrm{~A}$ & $0,15 \mathrm{~A}$ & $0 \mathrm{~A}$ \\
\hline 10 & & $0,16 \mathrm{~A}$ & $0,15 \mathrm{~A}$ & $0,01 \mathrm{~A}$ \\
\hline
\end{tabular}

\section{Pengujian Rangkaian Sensor Tegangan AC}

Pengujian ini dilakukan untuk memenuhi syarat alat ukur dengan toleransi kesalahan nilai sebesar 1-2\% [9]. Perangkat keras yang dirancang sebelumnya telah dikalibrasi sesuai dengan library perangkat lunak yang digunakan [8].

Pengujian dilakukan dengan membandingkan hasil pembacaan rangkaian sensor tegangan $\mathrm{AC}$ dengan multi tester konvensional kelas B (Hioki 3288-20) dengan mengukur tegangan pada jaringan listrik PLN yang mensuplai rangkaian utama sebanyak 5 kali. Berdasarkan pengujian yang dilakukan, selisih nilai pembacaan paling besar adalah 0,3 Volt (V) yang ditunjukan pada Tabel III.

TABEL III

Hasil Pengujian RangKaian Sensor Tegangan AC

\begin{tabular}{|c|c|c|c|}
\hline \multirow{2}{*}{ No. } & \multicolumn{2}{|c|}{ Hasil Pembacaan } & \multirow{2}{*}{ Selisih } \\
\cline { 2 - 3 } & Multi Tester & Sensor Tegangan & \\
\hline 1 & $229,6 \mathrm{~V}$ & $229,3 \mathrm{~V}$ & $0,3 \mathrm{~V}$ \\
\hline 2 & $229,5 \mathrm{~V}$ & $228,8 \mathrm{~V}$ & $0,3 \mathrm{~V}$ \\
\hline 3 & $229,6 \mathrm{~V}$ & $229,3 \mathrm{~V}$ & $0,3 \mathrm{~V}$ \\
\hline 4 & $229,4 \mathrm{~V}$ & $229,1 \mathrm{~V}$ & $0,3 \mathrm{~V}$ \\
\hline 5 & $229,4 \mathrm{~V}$ & $229,3 \mathrm{~V}$ & $0,1 \mathrm{~V}$ \\
\hline
\end{tabular}

4. Pengujian Rangkaian Sensor Cahaya

Rangkaian sensor cahaya diuji untuk mengetahui besar perwakilan nilai bit yang dihasilkan oleh rangkaian sensor cahaya. Pengujian dilakukan dengan membandingkan nilai bit yang dihasilkan rangkaian sensor cahaya dengan nilai lux menggunakan lux meter (merk Hioki) pada kondisi intensitas cahaya tertentu. Nilai bit yang dihasilkan rangkaian sensor cahaya ini digunakan sebagai indikator penyalaan lampu. 
Pengujian dilakukan pada sore hari menjelang malam mulai pukul 18.00 WITA sampai 18.30 WITA dalam selang waktu pengukuran setiap 5 (lima) menit. Hasil pengujian ditunjukan pada Tabel IV berikut.

TABEL IV

Hasil PENGujian RANGKaian SENSOR CAHAYA

\begin{tabular}{|c|c|c|c|}
\hline \multirow{2}{*}{ No } & \multirow{2}{*}{$\begin{array}{c}\text { Waktu } \\
\text { Pengukuran }\end{array}$} & \multicolumn{2}{|c|}{ Hasil Pembacaan } \\
\hline & & Lux Meter (lux) & Sensor Cahaya (bit) \\
\hline 1 & 18.00 WITA & 185,1 & 729 \\
\hline 2 & 18.05 WITA & 132,6 & 689 \\
\hline 3 & 18.10 WITA & 60,2 & 590 \\
\hline 4 & 18.15 WITA & 42,5 & 526 \\
\hline 5 & 18.20 WITA & 31,2 & 470 \\
\hline 6 & 18.25 WITA & 12.52 & 302 \\
\hline 7 & 18.30 WITA & 3,75 & 148 \\
\hline
\end{tabular}

Berdasarkan hasil pengujian, besar perwakilan nilai bit yang dihasilkan oleh rangkaian sensor cahaya digunakan pada pengaturan program sebagai indikator penyalaan lampu. Dimana dengan nilai bit $<500$ dengan nilai lux $<42,5$ lux maka lampu akan menyala dimmer sedangkan nilai bit $<300$ dengan nilai lux $<12,52$ lux maka lampu menyala maksimal.

\section{Pengujian Rangkaian RTC}

Rangkaian RTC diuji untuk dapat mengetahui rangkaian RTC bekerja dengan baik dengan membandingkan penunjukan waktu pada laptop yang digunakan saat pengujian. Pada pengujiannya rangkaian RTC dapat memberi informasi waktu pada mikrokontroler berupa menit, jam, hari, tanggal, bulan, dan tahun dengan output informasi waktu yang di tampilkan pada LCD yang ditunjukan pada Gambar 4.

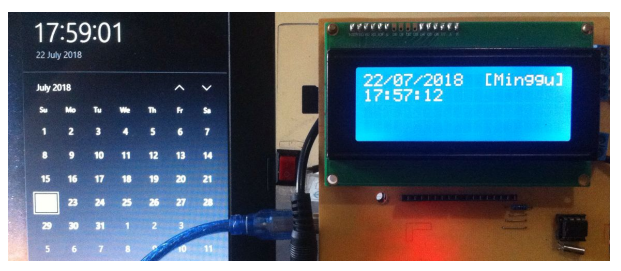

Gambar 4: Hasil Pengujian Rangkaian RTC

\section{Pengujian Rangkaian Micro SD Card}

Rangkaian micro SD card diuji untuk mengetahui kondisi rangkaian sudah dapat digunakan sebagai media penyimpanan data logger atau tidak, dengan informasi berupa tampilan pada LCD. Pengujian yang dilakukan ditunjukan pada Gambar 5.

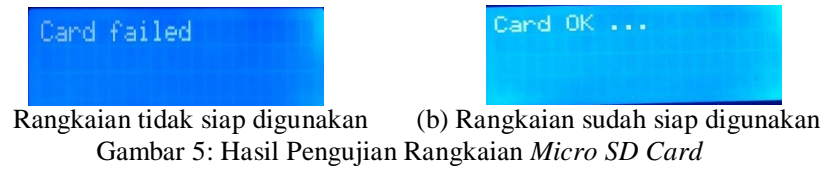

\section{Pengujian Rangkaian LED}

Rangkaian LED diuji untuk mengetahui pengaruh perubahan nilai PWM yang digunakan pada kontrol penyalaan lampu terhadap kuat pencahayaan lampu LPJU. Menggunakan rangkaian LED HPL 30W dengan sumber tegangan 12V DC. Hasil kuat pencahayaan lamu terhadap perubahan nilai PWM ditunjukan pada Tabel V.
TABEL V

Hasil Pengujian RANGKaian LED TERHADAP PERUBAHAN NILAi PWM

\begin{tabular}{|c|c|c|c|}
\hline No & Nilai PWM & Konndisi LED & Kuat pencahayaan (Lux) \\
\hline 1 & $255(100 \%)$ & Menyala & 45,3 \\
\hline 2 & $112(50 \%)$ & Menyala & 33,7 \\
\hline 3 & $90(40 \%)$ & Fliker & - \\
\hline 4 & $0(0 \%)$ & Padam & 0 \\
\hline
\end{tabular}

\section{Pengujian Pemodelan Sistem}

Pengujian dilakukan dengan menguji konsep sistem kerja rancang bangun alat sebagai kontrol penyalaan lampu dan monitoring konsumsi listrik. Berikut hasil pengujian pemodelan sistem yang dilakukan.

1. Pengujian Kontrol Penyalaan Lampu

\section{a. Pengujian I :}

Pada awal penyalaan lampu sore hari menjelang malam hari dengan indikator penunjukan waktu pukul 18.00 WITA dan nilai perwakilan bit sensor cahaya. Hasil pengujian yang dilakukan ditunjukan pada Gambar 6.

Penunjukan waktu pukul 18.00 WITA (a) lampu padam (b).

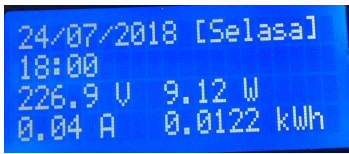

(a) Waktu pukul 18.00 WITA

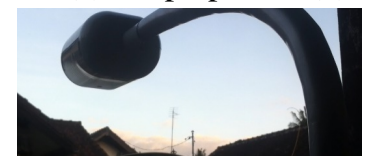

(b) Lampu padam
Penunjukan >pukul 18.00 WITA (c) lampu dimmer (d).

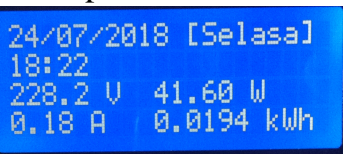

(c) Waktu >pukul 18.00 WITA

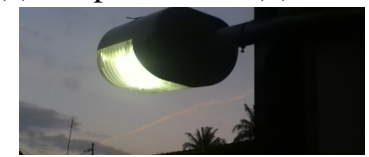

(d) Lampu menyala dimmer
Penunjukan >pukul 18.00 WITA (e) lampu menyala maksimal (f) sampai dengan pukul 00.00 WITA.

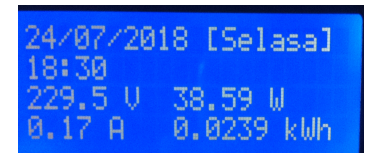
Gambar 6: Hasil Pengujian I (e) Waktu >pukul 18.00 WITA

\section{b. Pengujian II :}

Penunjukan waktu >pukul 00.00 (a) sampai <pukul 04.00 (b) maka lampu akan dimmer (b dan d). Hasil pengujian yang dilakukan ditunjukan pada Gambar 7.

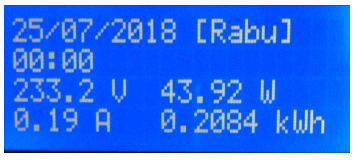

(a) Waktu >pukul 00.00 WITA

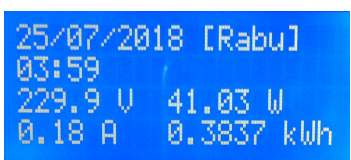

(b) Waktu <pukul 04.00 WITA

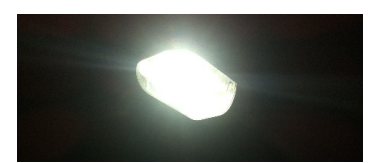

Lampu menyala maksimal

\section{Gambar 7: Hasil Pengujian II}

c. Pengujian III :

Penunjukan waktu >pukul 04.00 (a) sampai dengan <pukul 06.00 (c) maka kuat pencahayaan lampu maksimal (b dan e). Hasil pengujian ditunjukan pada Gambar 8. 

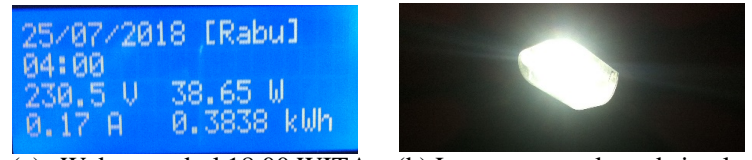

(a) Waktu >pukul 18.00 WITA

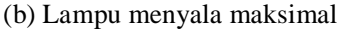

\section{$25 / 07 / 2018$ [Rabu] $65: 59$ \\ 227.9 ॥ 38.20 แ \\ 1.17 $\mathrm{H}$ 0.4528 kin}

(c) Waktu >pukul 18.00 WITA

Gambar 8: Hasil Pengujian III

d. Pengujian IV :

Penunjukan waktu > pukul 06.00 (a) lampu akan padam (b). Hasil pengujian ditunjukan pada Gambar 9.

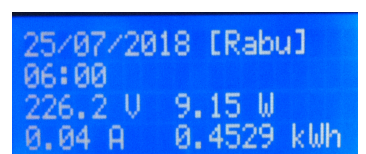

(a) Waktu >pukul 06.00 WITA

Gambar 9: Hasil Pengujian IV

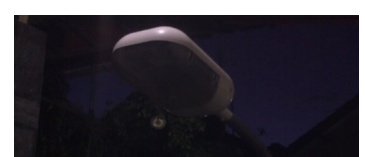

(b) Lampu padam

Setelah itu pada penunjukan >pukul 06.00 WITA (a) sampai <pukul 18.00 WITA (b) rangkaian utama standby ditunjukan pada Gambar 10. Dalam kondisi ini lampu padam dan rangkaian utama tetap beroperasi dengan tetap melakukan akumulasi konsumsi daya listrik, selaiin itu juga untuk memungkinkan digunakan diluar operasi normal yang dapat dioperasikan sewaktu-waktu sebagai monitoring oleh user yang ditunjukan pada Gambar 10.

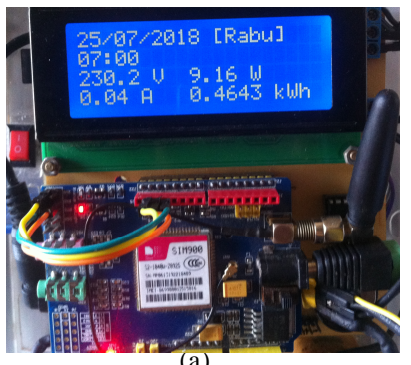

Gambar 10: Kondisi Rangkaian Utama Standby.

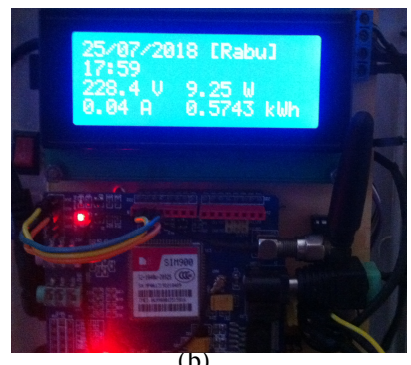

2. Pengujian Monitoring Konsumsi Listrik

Pengujian ini dilakukan untuk mengetahui akumulasi konsumsi daya listrik dapat didata logger serta mengirim dan menerima layanan SMS. Proses pengujian yang dilakukan dimulai dari Pengujian I yaitu melakukan data logger konsumsi daya listrik pada rancang bangun alat sebagai kontrol waktu penyalaan lampu yang dioperasikan selama 3 (tiga) hari berturut-turut. Pengujian II mengirim informasi dari LPJU ke user dan Pengujian III melakukan permintaan informasi dari user ke LPJU.

\section{a. Pengujian I :}

Pengujian ini melakukan data logger akumulasi konsumsi daya listrik pada micro SD Card yang tersimpan secara otomatis setiap pukul 06.00 WITA. Data hasil perekaman data logger tersimpan dengan nama file "LOGGER.TXT" pada micro $S D$ card [7]. Besar ukuran file yang digunakan dalam pengujian adalah $1 \mathrm{~KB}$. Hasil pengujian ditunjukan pada Gambar 11.

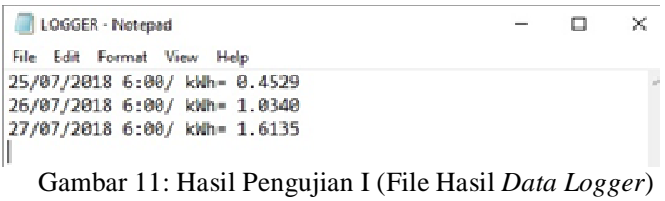

Akumulasi pengukuran konsumsi listrik pada pemodelan sistem rancang bangun alat yang dioperasikan selama 3 hari yang tersimpan pada data logger sebesar adalah $1,6135 \mathrm{kWh}$.

b. Pengujian II :

Pengujian ini melakukan pengiriman informasi dari LPJU ke user berupa pengiriman pesan SMS dengan informasi data akumulasi kWh oleh modul GSM ke nomor telepon user yang telah diprogramkan sebelumnya. Berikut hasil pengujian yang dilakukan pada Gambar 12.

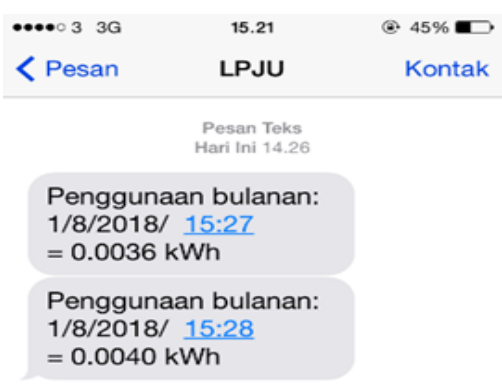

Gambar 7: Hasil Pengujian II

c. Pengujian III

Pengujian ini melakukan permintaan informasi sewaktuwaktu oleh user ke LPJU diluar operasi normal dengan mengirim SMS sesuai dengan format SMS "lapor". Berikut hasil pengujian yang dilakukan ditunjukan pada Gambar 8 .

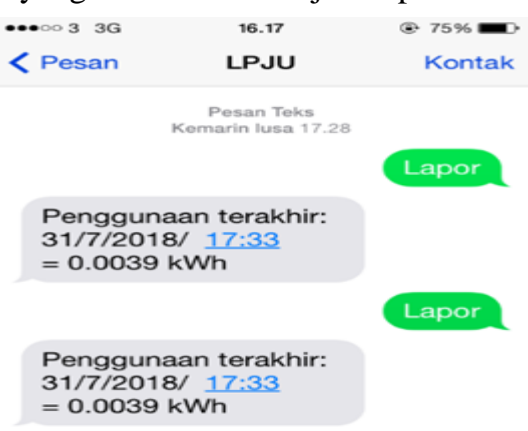

Gambar 8: Hasil Pengujian III

Berdasarkan pengujian pemodelan sistem yang dilakukan, realisasi rancang bangun alat kontrol dan monitoring konsumsi daya listrik berbasis mikrokontroler ATMega 2560 dapat beroperasi dengan baik sebagai kontrol penyalaan lampu menggunakan timer dan sensor cahaya sebagai indikator penyalaan lampu serta sebagai monitoring konsumsi daya listrik menggunakan layanan SMS. Keterbatasan dan kelemahan rancang bangun alat pada penelitian ini adalah hanya dapat beroperasi pada jaringan listrik PLN menyala dan beroperasi normal. Perancangan prototype pada 1 (satu) sumber sistem LPJU yang menggunakan LED DC dengan hasil pengujian yang dilakukan saat melakukan dimmer kuat 
pencahayaan hanya dapat menurun sebesar dengan nilai PWM $50 \%$ dan tidak mengalami penghematan konsumsi daya listrik.

\section{KESIMPULAN}

Simpulan yang dapat diambil berdasarkan hasil pengujian yang dilakukan adalah sebagai berikut:

1. Realisasi rangkaian perangkat keras dan perangkat lunak dapat berfungsi serta beroperasi dengan baik sesuai perancangan dan pengujian yang dilakukan.

2. Rancang bangun alat dapat melakukan kontrol lampu penyalaan dengan mengatur kuat pencahayaan lampu, dimana pada pukul 18.00 WITA lampu menyala dimmer pada nilai bit sensor cahaya $<500$, kemudian lampu akan menyala maksimal saat nilai bit sensor cahaya $<200$. Kemudian dapat melakukan penurunan kuat pencahayaan lampu pada >pukul 00.00 WITA sampai <pukul 04.00 WITA dan meningkatkan kembali kuat pencahayaan lampu maksimal pada >pukul 04.00 WITA sampai dengan pukul 06.00 WITA juga dapat mengatur waktu padam lampu pada >pukul 06.00 WITA sampai dengan < pukul 18.00 WITA.

3. Kuat pencahaayan lampu pada jenis lampu yang digunakan dengan pengaruh perubahan nilai PWM 100\% adalah 45,3 lux, PWM 50\% adalah 33,7 lux dan PWM 0\% adalah 0 lux. Penurunan kuat pencahayaan lampu saat menyala maksimal dengan lampu dimmer adalah 11,6 lux.

4. Perubahan nilai PWM terhadap kuat pencahayaan lampu antara $<50 \%$ sampai dengan $>0 \%$ mempengaruhi kondisi nyala lampu yaitu berkedip. Hal ini dikarenakan adanya minimal sumber tegangan pada lampu.

5. Monitoring menggunakan layanan SMS dari LPJU ke user dan user ke LPJU dapat direalisasikan.

\section{REFERENSI}

[1] Dinas Perhubungan Kota Denpasar. Studi Jaringan LPJU Kota Denpasar. CV. Penjor Dewata Hutama.. 2017.

[2] W Timotius. Effisiensi Penerangan Jalan Umum Menggunakan Sensor Gerak Berbasis Mikrokontroler. Prosiding Seminar Nasional Sains dan Pendidikan Sains IX. Semarang: Fakultas Sains dan Matematika, Universitas Kristen Satya Wacana. 2014.

[3] $\mathrm{T}$ Syamsuri. Kontrol Lampu Jalan Untuk Menghemat Energi. Prosiding SENTIA, Volume 7 -ISSN:2085-2347. Malang : Politeknik Negeri Malang. 2015.

[4] Sanjaya M, Cok Gede Indra Partha dan Duman Care Khrisne, "Rancang Bangun Sistem Data Logger Berbasis Visual Pada Solar Cell”, Junrnal Teknik Elektro, Vol.16, No.03, September-Desember. Universitas Udayana. 2017.

[5] Parmana I.W.R, Cok Gede Indra Partha, Ngakan Putu Satriya Utama, "Rancang Bangun Sistem Monitoring Arus Beban Pada Gardu Distribusi Menggunakan Short Message Sevice". Majalah Ilmiah Teknologi Elektro, Vol.17, No.1, Januari-April. Universitas Udayana. 2018.

[6] Suardiana I.M.N, I Gusti Agung Putu Raka Agung, Pratolo Rahardjo, "Rancang Bangun Sistem Pembacaan Jumlah Konsumsi Air Pelanggan PDAM Berbasis Mikrokontroler Atmega328 Dilengkapi Sms”. Jurnal Teknologi Elektro. Vol.16, No.1, Januari-April. Universitas Udayana. 2017.

[7] Rudito Prayogo. Pengaturan PWM (Pulse Width Modulation) dengan PLC. Malang. Universitas Brawijaya. 2012.

[8] Cekdini \& Barlian. 2013. Rangkaian Listrik. Yogyakarta.

[9] Wall R. A Report On The Properties Of The YHDC Current Transformer and Its Suitability For Use With The Open Energy Monitor. 2018

[10] PT.PLN (Persero). Instrumen dan Pengukuran Listrik. https://www.slideshare.net. 